\title{
MAJALAH MANGLE: PENJAGA KEARIFAN LOKAL DAN PERANANNYA DALAM MELESTARIKAN BAHASA DAN BUDAYA SUNDA 1957 -1998
}

\author{
Hilman Rosmana
}

Arsip Nasional Republik Indonesia

Jl. Ampera Raya Cilandak Jakarta Selatan

Alamat korespondensi: hilman_rosmana17@yahoo.com

Diterima/ Received: 7 Februari 2017; Disetujui/ Accepted: 28 Februari 2017

\begin{abstract}
This article analyzes on the development of Mangle as local magazine in the mid of modernization and its role to preserved Sundanese cultural heritage. There are three periods that successfully divided to analyze the development of the magazine, pioneering (1957-1959), triumph (1959-1972), and surviving (1972-1998) periods. By using historical method, it can be revealed conditions and problems faced by the editor of Mangle in each period. In the meantime, there are several factors that led the existence of Mangle for more than half a century. Some of these factors are 1) editorial persistence in maintaining commitment, 2) ability to present information according the reader's needs and wishes, and 3) reader loyalty. Mangle proved faithfully to be a preservation media for Sundanese culture. Through the editorial teams, Mangle was successfully managed to maintain the author's regeneration by let the new generation of Sundanese writers involved into the magazine pubilcation.
\end{abstract}

Keywords: Mangle; Preservation media; Sundanese culture

Abstrak

Artikel ini menganalisis mengenai perkembangan Majalah Mangle di tengah-tengah modernisasi dan peranannya dalam melestarikan kebudayaan Sunda. Terdapat tiga periode dalam perjalanan media cetak lokal ini, yaitu perintisan (1957-1959), kejayaan (1959-1972), dan bertahan (1972-1998). Dengan menggunakan metode sejarah dapat diungkap kondisi dan permasalahan yang dihadapi redaksi Majalah Mangle pada setiap periodenya. Sementara itu, terdapat beberapa faktor yang menyebabkan eksistensi Mangle selama lebih dari setengah abad. Beberapa faktor tersebut adalah kegigihan redaksi dalam menjaga komitmen, kemampuan menyajikan informasi yang sesuai dengan keinginan pembaca, dan loyalitas pembaca. Mangle terbukti setia menjadi media perjuangan masyarakat Sunda dalam menjaga dan mengembangkan kebudayaannya. Majalah Mangle melalui tokoh-tokoh redakturnya berhasil menjaga kesinambungan regenerasi penulis dengan memberikan akses penerbitan kepada generasi muda Sunda.

Kata Kunci: Mangle; Media pelestarian; Kebudayaan Sunda

\section{PENDAHULUAN}

Nasionalisme orang Sunda yang ditandai dengan pertumbuhan kesadaran politik suku Sunda, telah dibangun sebelum kemerdekaan Indonesia diproklamasikan. Sebuah organisasi yang bergerak di bidang sosial budaya bernama Vereeniging Pasoendan didirikan di Batavia pada 1914. Organisasi ini muncul sebagai reaksi atas Budi Utomo yang hanya diperuntukkan bagi 
masyarakat Jawa. Pada awal pendiriannya, Vereeniging Pasoendan ini bersifat kooperatif dengan Belanda. Namun, pada perkembangannya kemudian melalui organ politiknya yaitu koran Sipatahoenan mulai memberikan kritik kepada pemerintahan Hindia Belanda, sehingga harian ini dikenai persbreidelpada $1934 .^{1}$

Satu dasawarsa setelah kemerdekaan, seiring dengan perkembangan politik Indonesia sebagian kalangan masyarakat Sunda mempertanyakan mengenai kehidupan dan partisipasi politik mereka sebagai bagian dari masyarakat Indonesia. Hasil penilaian atas hal tersebut menyatakan bahwa orang Sunda harus mengakui bahwa mereka berada pada posisi inferior. Oleh karena itu pada Novemver 1957 masyarakat Sunda membentuk Badan Musyawarah Sunda (Bamus Sunda), yang mengikat 17 organisasi kesundaan. Pembentukan organisasi ini diharapkan dapat memberikan harapan baru kearah peningkatan derajat orang Sunda dan merupakan upaya ke arah Sunda Tunggal (Kesatuan Sunda) dengan tujuan bersatu dalam satu tekad, yaitu dalam rangka meningkatkan harkat derajat Sunda dalam lingkungan Negara Indonesia (Mangle, Mangle, No. 2, Desember 1957).

Seiring dengan kelahiran Badan Musyawarah Sunda (Bamus Sunda), sebagian kalangan masyarakat terpelajar Sunda berpendapat bahwa partisipasi politik suku Sunda pascakemerdekaan dapat dilakukan melalui bidang lain. Di kalangan kelompok budayawan Sunda, partisipasi orang Sunda dimaknai dengan pentingnya menjaga kelestarian bahasa dan kebudayaan suku Sunda sebagai bagian dari kebudayaan nasional. Kelompok ini menengarai kemunduran penggunaan bahasa dan kebudayaan Sunda, dan merasa prihatin akan kesinambungan pewarisan bahasa dan budaya Sunda kepada generasi muda. Kesadaran mengenai pentingnya melestarikan bahasa dan kebudayaan suku Sunda sebagai bagian dari jati diri kesundaan, melahirkan keinginan untuk menerbitkan sebuah majalah hiburan berbahasa Sunda. Majalah yang lahir seiring dengan kelahiran Badan Musyawarah Sunda (Bamus Sunda) tersebut diberi nama Mangle, dan oleh para pendirinya didedikasikan sebagai gerbang penjaga bahasa dan kebudayaan Sunda.

\section{HASIL DAN PEMBAHASAN}

\section{Jati Diri di Tengah Modernisasi}

Mangle yang dirintis penerbitannya oleh M.A. Salmoen, Otoen Mochtar, Wahyoe Wibisana serta Saleh Danasasmita, berorientasi pada idealisme nonkomersial, yaitu pers lokal sebagai alat untuk memajukan dan melestarikan kebudayaan Sunda. Penerbitan lokal ini dimulai dari pengamatan para pendirinya terhadap kebangkitan, kemunculan dan kendala pers lokal, utamanya pers Sunda dalam mempertahankan eksistensinya, yakni adanya faktor kegagalan redaksi untuk meneguhkan dan menempatkan diri sebagai penerbitan yang mampu mempertahankan simpati pembacanya. Bertolak dari hal tersebut, maka redaksi Mangle memutuskan untuk mengemas misi melestarikan bahasa dan budaya Sunda dalam bentuk majalah hiburan berbahasa Sunda. Keputusan tersebut diambil dengan pertimbangan bahwa misi redaksi dapat tercapai, di pihak lain pembacanya mendapat hiburan dari setiap tulisan yang dibacanya tanpa merasa dibebani oleh misi pewarisan bahasa dan budaya Sunda.

Dilihat dari isinya, Kandungan isi Mangle menyerupai isi Bromartani yang mencakup berbagai hal, meminjam istilah Ahmat Adam 'seolah penerbitannya ditujukan kepada siswa sekolah dan untuk pembaca umum' (Adam, 2003:21). Dalam setiap nomor penerbitan, Mangle mengisi halaman-halamannya dengan informasi yang bersifat pendidikan dan kebudayaan. Dengan demikian, kelahiran Mangle di wilayah Jawa Barat menjadi jawaban bagi sebagian guru bahasa Sunda untuk menyelesaikan persoalan kesulitan bahan ajar dan bacaan untuk pelajaran menulis dan membaca Sunda. Oleh karena itu, kecuali peranannya sebagai bacaan masyarakat umum, kedudukan Mangle dalam dunia pendidikan tidak jauh berbeda Bromartani dan Poespitaman-tjawarna yang disebut oleh Ahmat Adam juga menduduki tempat penting dalam bidang pendidikan, karena faktor isi dan bahasa 
(Adam, 2003:21). Konsep Bromartani tersebut juga diadaptasi oleh para pendiri Mangle untuk memberi bentuk majalah ini. Rubrik Manglejuga menunjukkan prototipe yang serupa dengan Bromartani, yakni keanekaragaman berita dan materi penulisan.

Kedudukan Mangle sebagai sarana penyedia informasi memiliki tempat tersendiri bagi sebagian besar pembacanya. Sebagai vernaculer pers, majalah ini lebih didominasi oleh informasi lokal yang lingkup spasialnya sebatas wilayah kebudayaan Sunda, dibanding dengan berita-berita berskala nasional atau pun internasional. Oleh karena itu, jumlah pembacanya tentu tidak dapat disejajarkan dengan majalah hiburan berskala nasional. Namun demikian, pada kurun waktu kejayaannya tiras Mangle mampu mengungguli majalah hiburan berskala nasional yang terbit di Jakarta.

Pada masa kejayaannya, kecintaan orang Sunda kepada majalah ini, yang ditunjukkan melalui partisipasi sebagai pembaca fanatik, menjadikan Mangle sebagai media penerangan yang cukup efektif untuk menyebarkan informasi resmi dari pemerintah di seluruh wilayah kebudayaan Sunda. ${ }^{2}$ Dengan demikian fungsi pers secara universal yaitu: memberikan informasi, mendidik, menghibur dan memengaruhi dapat dipenuhi oleh Mangle, bahkan di wilayah pedesaan penggunaan bahasa Sunda menjadikan informasi lebih dapat diterima (Effendy, 1986: 116). Demikian juga fungsi Mangle sebagai pers daerah: sebagai media komunikasi lokal, memberikan informasi kepada masyarakat mengenai segala sesuatu yang berkaitan dengan kebudayaan dan bahasa Sunda, mendidik pembaca melalui artikel dan berita yang disajikan, menghibur melalui rubrik-rubrik yang bersifat humor dan bacaan ringan, dapat dicapai. Selain itu Mangle juga memberi ruang gerak yang cukup lapang bagi penulis dan pemerhati kebudayaan dan sastra Sunda, untuk menyampaikan pendapatnya dalam satu media penerbitan yang berfungsi sebagai forum komunikasi kultural orang Sunda.

Citra Mangle sebagai pers mandiri terlihat dari beberapa unsur penerbitan sebagaimana pendapat Anwar Arifin yang mengkaitkan citra pers dengan unsur ideologi pers, pemimpin pers, dan kepentingan yang dilayani oleh pers (Arifin, 2010: 18-19). Dari sudut pandang ideologi pers, pemimpin pers, dan kepentingan yang dilayani oleh pers memberikan gambaran yang menarik.

Pertama, berdasar pengelompokan kekuatan politik dan pertumbuhan idiologi di Indonesia 1950-1965, ideologi Mangle berada di luar lingkaran politik, walaupun secara teoretik terdapat keterkaitan antara pers dengan politik dan dengan dinamika politik. Dalam konteks tersebu, maka ideologi Mangle hanya dapat dijelaskan dalam kaitannya dengan nasionalisme primordial-kedaerahan, yaitu idealisme pada ranah kebudayaan, melestarikan dan mengembangkan kebudayaan yang diterjemahkan dalam bahasa Sunda ngamumule kabudayan Sunda

Kedua, Pemimpin Redaksi Mangle yang oleh Anwar Arifin disebut dengan pemimpin pers bukanlah bagian dari individu yang terlibat langsung dalam kehidupan partai politik atau menjadi pendukung partai politik tertentu. Mereka adalah individu-individu yang tidak tertarik pada bidang politik, dan sejak awal penerbitan Mangle telah dideklarasikan sebagai majalah yang bebas dari pengaruh isme, pengaruh partai atau kelompok. ${ }^{3}$

Ketiga, kepentingan yang dilayani pers sebagaimana disebut oleh Anwar Arifin menunjuk pada pemenuhan kebutuhan dan kepentingan massa, yakni para pembacanya. Dari persepektif ini, terlihat bahwa Mangle diterbitkan untuk melayani kebutuhan masyarakat Sunda secara umum, yaitu dalam bidang aktualisasi budaya dan bahasa, di luar bidang politik. Dengan demikian, Mangle dapat dikategorikan sebagai pers mandiri, yaitu pers yang tidak terkait secara formal dengan organisasi sosial atau organisasi politik atau dengan pemerintah.

Selain sebagai pers mandiri, citra Mangle sebagai majalah hiburan bermisi pelestarian bahasa dan budaya Sunda tampak dalam penampilannya di setiap penerbitan. Kedudukan dan fungsi bahasa Sunda sebagai alat komunikasi verbal yang dijaga kelestariannya, tampak dalam penggunaan bahasa Sunda dalam setiap tulisan 
yang ada. Dengan demikian bahasa Sunda diletakkan dalam kedudukannya sebagai alat verbal untuk menyampaikan pokok bahasan, sekaligus sebagai objek bahasan. Hal tersebut tercermin dari banyaknya bahasan mengenai Sunda, seperti pangajaran bahasa Sunda. Citra sebagai majalah hiburan digambarkan secara jelas dengan isi rubrik-rubrik yang menampilkan tulisan-tulisan ringan seperti prosa dalam berbagai bentuk seperti cerita pendek, cerita bersambung, puisi, dan lain sebagainya sehingga Mangle disebut sebagai majalah panglipur (hiburan).

\section{Perjuangan Sepanjang Tahun Penerbitan}

Episode kehidupan majalah Mangle dibagi dalam tiga periode, yaitu Periode Perintisan (1957-1959), Periode Kejayaan (1959-1972), dan Periode Bertahan (1972-1998). Setiap periode dilewati dengan berbagai permasalahan yang dapat diselesaikan oleh redaksi Mangle dengan bermacam cara.

\section{Periode Perintisan(1957-1959)}

Sejak penerbitan pertama redaksi terus berupaya untuk membuat tampilan yang menarik. Beberapa upaya perbaikan dilakukan, termasuk membuat rubrik yang jelas karena pada awal penerbitan tidak terlihat pengaturan rubrik yang baik, sehingga terkesan seadanya. Pada periode ini, identitas Mangle sebagai majalah umum bernapas bahasa dan budaya Sunda telah terlihat jelas, yang ditandai dengan penggunaan bahasa Sunda dan tulisan-tulisan yang berkaitan dengan bahasa, sastra dan budaya Sunda. Gambar sampul - seorang wanita - pada tahun-tahun seterusnya dipertahankan dan menjadi identitas majalah Mangle.

Keanekaragaman rubrik seolah menunjukkan bahwa Redaktur Mangle berniat untuk ngamumule budaya Sunda, sehingga semua rubrik yang dihadirkan kepada pembacanya merupakan cerminan dari setiap usaha untuk memuliakan dan merawat budaya Sunda. Dalam kajian budaya dikenal segitiga budaya dengan tiga sudut, yakni: tujuan kultural, postulat kultural, cara atau mekanisme kultural untuk mencapai tujuan itu. Tujuan kultural orang Sunda adalah: hidup sejahtera, hati tenteram dan tenang, mendapat kemuliaan, damai, merdeka untuk selamanya, dan mencapai kesempurnaan di akherat. Postulatnya ada sekitar 15 butir, tetapi intinya mengerucut pada sifat-sifat ideal, antara lain, hurip, waras, kirab sawan, cageur, bageur, bener, pinter, ludeung, silih asah, silih asih, dan sineger tengah (Alwasilah, 2006: 12).

Manajemen perusahaan dilakukan dengan menggunakan manajemen keluarga karena pemilik perusahaan adalah salah seorang pendiri majalah Mangle, yaitu Oeton Mochtar. Dewan Redaksi diserahkan kepada Wahyu Wibisana dan Saleh Danasasmita, sedang Abdullah Romli sebagai pembantu. Ny. E. Rochamina Sudarmika diserahi tugas untuk menjadi Direktur perusahaan. Mas Atje Salmun ditempatkan sebagai pendamping atau penasehat.

Di tengah-tengah dukungan berbagai kalangan termasuk orang-orang Sunda yang tinggal di luar wilayah Jawa Barat yang menganggap kelahiran majalah Mangle sebagai kelahiran baru pers Sunda, kelahiran majalah ini menuai kritik dari kelompok masyarakat yang menganggap Mangle sebagai penerbitan yang tidak ada manfaatnya (Mangle, No. 2, Desember 1957). Menyikapi kritik tersebut, redaksi terus berusaha untuk meningkatkan kualitas penerbitan majalah ini, sehingga mengantar Mangle ke puncak masa kejayaannya. Persoalan keuangan, yaitu yang berkaitan dengan tunggakan pembayaran langganan dapat diselesaikan melalui penagihan kepada agenagen dan para pembaca.

\section{Periode Kejayaan (1959-1972)}

Pada periode ini terdapat perubahan yang terjadi pada konten dan manajemen Mangle yang menyebabkan majalah ini mampu meraih kesusksean. Pertama, perubahan pertama yang tampak menonjol sebagai akibat dari banyak ragam tulisan yang dikirim yaitu peluang redaksi untuk menata ulang penampilan majalah menjadi lebih baik. Peningkatan kuantitas dan kualitas tulisan serta ragam tulisan memungkinkan redaksi mengembangkan format majalah, sehingga pembagian rubrikasi menjadi lebih jelas, menghilangkan kesan semrawut dan 
memberi kesan lebih teratur pada tata letak majalah Mangle. Pada saat itu muncul rubrik baru yaitu pengajaran bahasa Sunda. Tekanan bahasa asing terhadap bahasa lokal, terutama bahasa Sunda menjadi sebab utama lahirnya kolom pengajaran bahasa Sunda pada majalah Mangle (Wibisana, 2011:5)

Keberhasilan terbesar dalam sejarah perjalanan majalah Mangle adalah kemampuannya mencapai tiras mendekati 100.000 eksemplar di setiap penerbitannya. Keberhasilan ini dicapai setelah redaksi berhasil mewujudkan majalah yang sesuai dengan keinginan pembaca, yaitu tata letak yang baik, isi yang menarik, serta penampilan yang semakin baik.

Kesan semrawut dapat dihilangkan dengan rubrikasi yang jelas dan tata letak yang semakin baik. ${ }^{4}$ Kehadiran tulisan-tulisan para penulis Sunda senior dan terkenal dengan karyakaryanya yang sesuai dengan keinginan pembaca, mengakibatkan jumlah pembaca semakin meningkat. Artikel-artikel yang beragam, yang datang dari berbagai kalangan memudahkan redaksi untuk memilih tulisan yang sesuai dengan citra Mangle, sehingga kualitas isi Mangle semakin membaik. Periode ini juga ditandai dengan kenaikan jumlah halaman Mangle, sehingga harga majalah ini secara bertahap mengalami kenaikan. Manajemen perusahaan pada periode ini masih dilakukan dengan menggunakan manajemen keluarga, namun beberapa pengarang terkenal masuk dan menjadi bagian dari redaksi, sehingga mampu memperkaya pemikiran peningkatan kualitas Mangle.

Pada periode kejayaan, utamanya sekitar 1963-an, dinamika politik dan gerak perubahan politik pemerintah pada masa puncak kekuasaan Presiden Soekarno berpengaruh kepada situasi politik Indonesia secara umum, termasuk di dalamnya kehidupan penerbitan Mangle. Sebagai majalah umum yang sejak awal kelahirannya telah mengikrarkan diri lepas dari kekuatan dan pengaruh partai serta paham apa pun, ternyata tidak cukup untuk dapat melepaskan diri sama sekali dari iklim politik saat itu. Idealisme sebagai pers mandiri dalam batasan tertentu tampak tercampur dengan kepentingan penguasa, yaitu memberikan tempat yang cukup banyak bagi informasiinformasi yang berkaitan dengan program politik pemerintah. Pada 1960-an membuktikan bahwa Mangle telah digunakan oleh pemerintah untuk menyuarakan program-programnya.

\section{Periode Bertahan (1972-1998)}

Periode ini ditandai dengan kemunduran tiras majalah Mangle yang menyusut dari waktu ke waktu. Tiras majalah ini dari 100.000 eksemplar menyusut ke kisaran 50.000 dan bertahan mendekati rata-rata antara 10.000 sampai 5.000 eksemplar setiap terbitnya. Kemunduran ini disebabkan oleh berbagai masalah, utamanya adalah kemunduran minat orang Sunda kepada pers lokal.

Pada periode ini, banyak pers Sunda yang mengalami gagal terbit karena kehilangan pembacanya. Ketiadaan dukungan dari pemerintah terhadap keberadaan pers lokal, yang salah satunya ditandai dengan pengunduran diri sebagai langganan Mangle pada hampir seluruh instansi pemerintah di Jawa Barat termasuk sekolah-sekolah, menjadi salah satu faktor menurunnya tiras Mangle. Redaksi tidak dapat mempertahankan apalagi meningkatkan tirasnya karena sebagian masyarakat Sunda tidak menganggap penting kehadiran majalah Mangle dirumah mereka.

\section{Peranan Mangle dalam Mendorong Vitalitas Bahasa dan Perkembangan Kebudayaan Sunda}

Dalam kerangka mendorong peningkatan penggunaan bahasa Sunda dalam berbagai kalangan dan untuk berbagai keperluan, Mangle menempatkan dirinya sebagai majalah panglipur yang lebih mengedepankan fungsinya sebagai majalah hiburan, namun terus berupaya tetap menjadi ajang apresiasi sastra Sunda. Dengan cara demikian, redaksi mengajak pembaca untuk menikmati sastra Sunda tanpa mengharuskan untuk berkutat dengan teori sastra. Dengan langkah itu Mangle rupanya telah mengajak pembacanya bukan saja sebagai pembaca sastra Sunda, tetapi juga sebagai penikmat sastra Sunda. Sekat antar tingkat bahasa yang sering kali menjadi kendala penggunaan bahasa disikapi 
dengan cara yang bijaksana, yakni menggunakan bahasa loma sebagai pilihan, sehingga semua kalangan dapat menggunakan bahasa pada tingkat tersebut sebagai alat komunikasi. Melalui karya-karya tersebut, maka Mangle telah memberikan bantuan pengajaran bahasa dan sastra melalui jalur pendidikan informal, sekaligus menunjukkan kepada pembaca bahwa bahasa Sunda dapat digunakan untuk menulis artikel-artikel yang bersifat ilmiah, atau dengan kata lain bahasa Sunda dapat berfungsi sebagai bahasa ilmu pengetahuan dan pemerintahan.

Andil terbesar majalah Mangle dalam kehidupan sastra Sunda adalah peranannya dalam melahirkan generasi baru penulis Sunda. Redaksi Mangle membangun tahapan 'kelahiran penulis baru' melalui empat unsur pembentukan penulis, yaitu: (1) Semangat, yakni memberikan dorongan semangat berkarya kepada generasi muda; (2) Media, yakni menyediakan tempat di majalah Mangle untuk menampilkan tulisan; (3) Apresiasi, memberikan apresiasi atau penilaian atas karya yang telah dimuat; (4) Pembelajaran, yakni menciptakan ruang yang memungkinkan para penulis muda berguru kepada penulis senior. Secara terperinci, tahapan pembibitan generasi muda penulis Sunda tersebut dapat dijabarkan sebagai berikut. Pertama, adalah menjaring penulis muda dan menemukan potensi dan bakat terpendam yang belum terasah. Tahapan ini dilakukan dengan memuat tulisan karya penulis baru yang telah diseleksi redaksi Mangle, berdampingan dengan hasil karya para penulis senior. Model pemuatan naskah yang demikian kiranya dimaksudkan sebagai pemberian dorongan semangat kepada penulis baru bahwa karya mereka berada pada kedudukan sejajar dengan hasil karya para penulis Sunda senior. Tahapan ke dua, berupa pemberian apresiasi kepada hasil karya setiap penulis berupa honor tulisan dan melalui rubrik apresiasi sastra. Rubrik ini memberikan kesempatan kepada setiap pembaca untuk mengkritisi hasil karya yang dimuat dalam majalah Mangle. Rubrik ini dikemas oleh redaksi dengan nama Bale Rancage dan Koropak Mangle. ${ }^{5}$ Cara ini memungkinkan penulis melihat tanggapan masyarakat atas hasil karyanya dan dapat memperbaiki kekurangan yang dimilikinya. Cara ini juga berperan dalam membentuk karakter penulisan sebagai ciri khas masing-masing penulis. Selanjutnya, pertemuan para penulis muda dengan para penulis senior, menjalin keterikatan emosisonal sesama penulis dan ajang transfer ilmu serta pengalaman dari penulis-penulis senior kepada penulis-penulis muda. Kelahiran generasi baru penulis Sunda ditunjukkan dengan berbagai karya dalam bahasa yang berbeda dengan penulis senior. Kaderisasi penulis muda melalui majalah Mangle telah melahirkan penulis tingkat nasional seperti Dedy Iskandar dan Aam Amalia.

\section{SIMPULAN}

Majalah Mangle terbit atas inisiatif sekelompok nasionalis Sunda yang bergerak pada ranah kultural. Penerbitan ini dilatarbelakangi oleh keinginan untuk melestarikan bahasa, sastra dan kebudayaan Sunda. Dalam perjalanannya, majalah Mangle melalui tiga periode yang penuh perjuangan, yaitu Periode Perintisan, Periode Kejayaan dan Periode Bertahan. Kemampuan redaksi mempertahankan eksistensi Mangle didukung oleh pembaca fanatik yang tetap setia berlangganan sampai saat ini. Peran terbesar dari majalah ini adalah melahirkan generasi baru penulis Sunda yang mampu membuktikan dirinya sebagai penulis tingkat nasional.

\section{CATATAN}

1"Toepassing persbreidel op de Sipatahoenan orgaan van de Vereeniging Pasoendan”, (C/45 Sipatahoenan, ANRI). Arsip yang tersimpan di ANRI ini merupakan hasil reproduksi, arsip asli tersimpan di Nationaal Archives Nederland (NAN)-Denhaag.

${ }^{2}$ Informasi mengenai wilayah peredaran/penyebaran Mangle, periksa Mangle No 157, Tahun XI, 30 Maret 1968

${ }^{3}$ Meskipun demikian, sebagaimana pada tahun 1960an Mangle pernah dijadikan sebagai salah satu media yang dipakai untuk menyosialisasikan programprogram politik pemerintah Orde Lama.

${ }^{4}$ Perkembangan rubrik ditunjukkan dengan munculnya rubrik baru seperti essai sastra dan budaya, Pangajaran Basa Sunda (Pelajaran Bahasa Sunda), Munara Cahya, yang merupakan rubrik agama Islam, dan lain sebagainya. 
${ }^{5}$ Apresiasi kepada tulisan yang dianggap istimewa pernah diberikan kepada Rustandi Kartakusumah berjudul 'Mercedes 190' dalam Mangle No. 115-119 dalam rubrik khusus 'Genjlong Mercedes 190'.

\section{REFERENSI}

Adam, Ahmat (2003). Sejarah Awal Pers dan Kebangkitan Kesadaran Keindonesiaan. Jakarta: Hasta Mitra Pustaka Utan Kayu.

Alwasilah, A. Chaedar (2006). Pokoknya Sunda: Interpretasi Untuk Aksi. Bandung: PT. Kiblat Buku Utama.

ANRI, “Toepassing persbreidel op de Sipatahoenan orgaan van de Vereeniging Pasoendan", C/45 Sipatahoenan.

Arifin, Anwar (2010). Pers dan Dinamika Politik: Analisis Media Komunikasi Politik Indonesia. Jakarta: Yarsif Watamponem.

Effendy, Onong U. (1986). Dimensi Dimensi Komunikasi. Bandung: Alumni.

Mangle No 157, Tahun XI, 30 Maret 1968.

Mangle No. 2, Tahun I, Desember 1957.

Wibisana, Wahyu (2011) Ngamumule Basa Sunda. Bogor: PT Kibat Buku Utama. 